\title{
PENGARUH ETIKA AUDITOR, PENGALAMAN AUDITOR DAN MOTIVASI AUDITOR TERHADAP KUALITAS AUDIT (Studi Empiris Kantor Akuntan Publik Kota Padang)
}

\author{
Elsa Fitri Amran ${ }^{(1)}$ dan Fitri Selvia ${ }^{(2)}$ \\ Institut Agama Islam Negeri Batusangkar \\ elsafitriamran@iainbatusangkar.ac.id ${ }^{(\mathbf{1})}$ \\ Sekolah Tinggi Ilmu Ekonomi Sumbar Pariaman \\ fitriselvia00@gmail.com ${ }^{(2)}$
}

This study aims to determine the effect of the ethics of auditor, experience of auditors, and motivation of auditors on quality of audits at the public accounting firm in the city of Padang. The sample selection of this study using convenience sampling. The data used are primary data obtained directly from the result of questionnaire distribution, with a sample of 68 respondents. The analytical tool used to test the hypothesis that multiple regression analysis using SPSS 16.0. The results showed that the variable ethics of auditor positive impact on the quality of audits big as 0,000 < 0,05 (sicnificant level), variable experience of auditor positive impact on the quality of audits big as 0,024 < 0,05 (sicnificant level), and variable motivation of auditors positive impact on the quality of audits big as 0,000<0,05 (sicnificant level).

Keywords: Ethics of Auditors, Experience of Auditors, Motivation of Auditors and Quality of Audit.

\section{PENDAHULUAN}

Persaingan bisnis sekarang ini mengalami perubahan yang signifikan, banyak perusahaan kecil menjadi besar dan perusahaan besar pun semakin berkembang pesat yang mengakibatkan kelonggaran baik dalam hal kuantitas maupun kualitas, hal ini diperlukan pengawasan yang cukup pesat dalam mengelola perusahaan agar perusahaan tersebut berjalan sesuai dengan tujuan perusahaan tersebut. Tetapi dengan pengawasan yang begitu ketat pun terkadang tidak mampu untuk mendeteksi serta mencegah adanya kecurangan (froud) yang terjadi dalam kegiatan perusahaan tersebut, khususnya kecurangan dalam laporan keuangan. Oleh karena itu diperlukan jasa audit yang dapat membantu mendeteksi serta menilai keandalan laporan keuangan, dalam masalah ini jasa tersebut yaitu jasa akuntan publik yang dalam penugasan auditnya dibutuhkan untuk menilai serta menentukan kewajaran laporan keuangan suatu perusahaan (Kartika, 2015).

Seorang auditor harus objektif dan untuk dapat melakukakan audit dengan baik sesuai standar yang harus dipenuhi oleh seorang auditor adalah memegang teguh etika profesi yang sudah ditetapkan dalam menjalankan tugasnya, agar situasi persaingan dapat dihindarkan. Akuntan yang professional dalam menjalankan tugasnya memiliki pedoman-pedoman yang mengikat dalam hal ini adalah Kode Etik Akuntan Indonesia, sehingga dalam menjalankan aktifitasnya akuntan publik memiliki arah yang jelas dan dapat memberikan keputusan yang tepat dan dapat di pertanggungjawabkan kepada pihak-pihak yang menggunakan hasil keputusan auditor. Sekalipun auditor seorang 
ahli, tetapi apabila dia tidak mempunyai pemahaman etika yang baik dalam pengumpulan informasi, maka informasi yang digunakan untuk mengambil keputusan tersebut tidak dapat di pertangggungjawabkan. Dengan kata lain bahwa setiap auditor harus mempunyai pemahaman tentang Kode Etik Akuntan Indonesia agar setiap auditor tidak mudah dipengaruhi dan sikap itu harus tetap dipertahankan karena auditor seharusnya tidak memihak kepentingan siapapun dan auditor berkewajiban untuk jujur agar proses audit dapat dipercaya oleh semua pihak yang berkepentingan terutama masyarakat (Amrizal, 2014).

De Angelo (1981) dikutip dari (Simanjuntak, 2008) mendefinisikan kualitas audit merupakan segala kemungkinan dapat terjadi dimana auditor dapat menemukan pelanggaran yang terjadi dalam sistem akuntansi klien pada saat mengaudit laporan keuangan klien dan melaporkannya dalam laporan keuangan auditan, dimana auditor dalam melaksanakan tugasnya tersebut harus berpedoman pada standar auditing dan kode etik akuntan publik.

Penelitian tentang pengaruh terhadap kualitas audit yang pernah dilakukan antara lain: Penelitian oleh (Ardini, 2010) yang menguji tentang pengaruh kompetensi, independensi, akuntabilitas dan motivasi auditor terhadap kualitas audit. Penelitian yang dilakukan oleh (Putra, 2012) yang menguji pengaruh kompetensi, tekanan waktu, pengalaman kerja, etika auditor, dan independensi auditor terhadap kualitas audit. Penelitian oleh (Hanjani, 2014) melakukan penelitian tentang pengaruh etika, pengalaman, fee audit dan motivasi auditor terhadap kualitas audit. Penelitan (Kartika, 2015) tentang pengaruh pengalaman auditor, etika auditor terhadap kualitas audit. Selanjutnya Penelitan tentang pengaruh terhadap kualitas audit juga dilakukan oleh (Mufidah, 2015) tentang pengaruh kompetensi, etika auditor dan fee audit terhadap kualitas audit. Pada penelitian ini akan lebih berfokus pada pengaruh etika auditor, pengalaman auditor dan motivasi auditor terhadap kualitas audit.

Penelitian ini melibatkan responden di Kantor Akuntan Publik yang ada di wilayah Kota Padang, Sumatera Barat. Alasannya karena kota Padang terdapat Kantor Akuntan Publik yang besar maupun kecil, yang menuntut eksistensi auditor independen dalam melakukan pemeriksaan terhadap laporan keuangan dalam memberikan pendapat atas dasar pemeriksaan, sehingga keterlibatannya dalam penentuan kualitas audit dan cukup representative untuk dilakukannya penelitian.

\section{KAJIAN PUSTAKA DAN PENGEMBANGAN HIPOTESIS}

\section{Kualitas Audit}

Sampai saat ini belum ada defenisi yang pasti mengenai apa dan bagaimana kualitas audit yang baik itu. Tidak mudah untuk menggambarkan dan mengukur kualitas audit secara obyektif dengan beberapa indikator. Hal ini dikarenakan kualitas audit merupakan sebuah konsep yang kompleks dan sulit dipahami, sehingga sering kali terdapat kesalahan dalam menentukan sifat dan kualitasnya. Hal ini terbukti dari banyaknya penelitian yang menggunakan dimensi kualitas audit yang berbeda-beda.

De Angelo (1981) dalam (Hanjani, 2014) mendefinisikan kualitas audit sebagai probabilitas dimana seorang auditor menemukan dan melaporkan tentang adanya suatu pelanggaran dalam sistem akuntansi kliennya. Proses pelaporan yang dilakukan oleh auditor tergantung kepada independensi auditor untuk mengungkapkan pelanggaran tersebut. Hasil penelitiannya menunjukkan bahwa Kantor Akuntan Publik (KAP) yang besar akan berusaha untuk menyajikan 
kualitas audit yang lebih besar dibandingkan dengan KAP yang lebih kecil.

\section{Etika Auditor}

Dalam menjalankan tugasnya seorang auditor harus mematuhi kode etik yang telah ditetapkan. Pelaksanaan audit harus mengacu pada standar audit ini, dan auditor wajib mematuhi kode etik yang merupakan bagian yang tidak terpisahkan dari standar audit. Kode etik ini bertujuan untuk mengatur hubungan antara : 1) Auditor dengan rekan sekerjanya, 2) Auditor dengan atasannya, dan 3) Auditor dengan auditan (objek pemeriksanya) serta, 4) Auditor dengan masyarakat.

\section{Pengalaman Kerja}

Terdapat beberapa alasan mengapa pengalaman audit mempengaruhi seorang auditor terhadap kualitas audit. Pengalaman menumbuhkan kemampuan auditor untuk mengolah informasi, membuat perbandinganperbandingan mental berbagaai solusi alternatif dan mengambil tindakan-tindakan yang diperlukan. Auditor yang belum berpengalaman, tidak memiliki kemampuan seperti itu. Dengan pengalaman audit mereka, auditor mengembangkan struktur memori yang luas dan kompleks yang membentuk informasi yang dibutuhkan untuk mengambil keputusan-keputusan.

\section{Motivasi Auditor}

Motivasi pada diri seseorang mendorong keinginan individu untuk melakukan kegiatan-kegiatan tertentu untuk mencapai tujuan (Reksohadiprodjo, (1990) dalam (Hanjani, 2014). Kualitas audit akan tinggi apabila keinginan dan kebutuhan auditor yang menjadikan motivasi kerjanya dapat terpenuhi. Kompensasi dari organisasi berupa penghargaan (reward) sesuai profesinya, akan menimbulkan kualitas audit karena mereka merasa bahwa organisasi telah memperhatikan kebutuhan dan pengharapan kerja mereka.

Untuk mendapatkan motivasi kerja yang positif didalam diri pegawai, maka seorang pemimpin harus sungguh-sungguh memberikan perhatian pada faktor-faktor sebagai berikut :

1. Keberhasilan

Pelaksanaan (Achievement)

2. Pengakuan (Recognition)

3. Pekerjaan itu sendiri (The Work it Self)

4. Tanggung jawab (Responsibillities)

5. Pengembangan (Advancement)

5. Pengembangan Hipotesis Penelitian Pengaruh Etika Auditor Terhadap Kualitas Audit

Seorang auditor dalam membuat keputusan pasti menggunakan lebih dari satu pertimbangan rasional yang didasarkan pemahaman etika yang berlaku dan membuat suatu keputusan yang adil, serta tindakan yang diambil itu harus mencerminkan kebenaran dan keadaan yang sebenarnya. Dalam menjalankan jasa professionalnya, auditor dirancang untuk memiliki pandangan yang realistis dan sedapat mungkin idealis. Berkaitan dengan etika, auditor tidak lepas dari standar dan prinsip-prinsip etika yang melekat dalam pribadi auditor. Prinsipprinsip etika dikatakan sebagai kerangka dasar bagi aturan etika yang mengatur pelaksanaan pemberian jasa professional oleh anggota (Hanjani, 2014). Dari pendapat di atas, peneliti mengajukan hipotesis sebagai berikut :

"H1 : Etika auditor berpengaruh positif terhadap kualitas audit"

\section{Pengaruh Pengalaman Auditor Terhadap Kualitas Audit}

Pengalaman akuntan publik akan terus meningkat seiring dengan makin banyaknya audit yang dilakukan serta kompleksitas transaksi keuangan perusahaan yang diaudit sehingga akan menambah dan 
memperluas pengetahuannya dalam bidang akuntansi dan bidang auditing. Hal tersebut mengidentifikasikan bahwa semakin lama masa kerja dan pengalaman yang dimiliki auditor maka akan semakin baik dan meningkat pula kualitas audit yang dihasilkan (Kartika, 2015).

Berdasarkan penjelasan diatas, maka hipotesis yang diajukan adalah :

"H2 : Pengalaman auditor berpengaruh positif terhadap kualitas audit"

\section{Pengaruh Motivasi Auditor Terhadap Kualitas Audit}

Apabila keinginan dan kebutuhan auditor yang menjadikan motivasi kerjanya dapat terpenuhi dengan baik maka kualitas audit pun akan semakin meningkat. Kompensasi dari organisasi berupa penghargaan (reward) sesuai profesinya, akan menimbulkan kualitas audit karena mereka merasa bahwa organisasi telah memperhatikan kebutuhan dan pengharapan kerja mereka. Dengan demikian, apabila seseorang atau auditor mempunyai kompetensi, independensi dan pengalaman maka akan mengarahkan atau menimbulkan motivasi secara profesional dengan adanya motivasi yang tinggi maka akan menambah kualitas audit (Ardini, 2010). Dengan demikian, dapat dikemukakan hipotesis sebagai berikut :

"H3: Motivasi auditor berpengaruh positif terhadap kualitas audit"

\section{Pengaruh Etika Auditor, Pengalaman Auditor, dan Motivasi Auditor berpengaruh secara simultan terhadap Kualitas Audit}

Etika auditor, pengalaman auditor dan motivasi auditor terhadap kualitas audit mempunyai hubungan erat secara bersamasama. Ketiga variabel tersebut merupakan tuntutan perusahaan kepada setiap auditor. Dengan demikian dapat dikemukakan hipotesis sebagai berikut :
"H4: Etika Auditor, Pengalaman Auditor, dan Motivasi Auditor berpengaruh secara simultan terhadap Kualitas Audit"

\section{METODE PENELITIAN}

\section{Jenis dan Sumber Data}

Data yang digunakan dalam penelitian ini adalah data primer yaitu data yang diperoleh secara langsung dari responden. Dalam hal ini data primer tersebut diperoleh dari hasil penyebaran kuesioner yang dilakukan peneliti kepada Kantor Akuntan Publik (KAP) di Kota Padang, Sumatera Barat.

\section{Metode Pengumpulan Data}

Metode pengumpulan data dalam penelitian ini diperoleh dengan menggunakan metode survey yaitu kuesioner. Kuesioner adalah suatu teknik pengumpulan data dengan cara membuat pertanyaan-pertanyaan yang diajukan penulis kepada pihak-pihak berkaitan dengan masalah yang diteliti. Kuesioner secara personal (personally administered questionnaires), yaitu untuk mengetahui seberapa besar peran etika auditor, pengalaman auditor, dan motivasi auditor terhadap kualitas audit.

\section{Populasi dan Sampel}

Populasi yang digunakan dalam penelitian ini adalah seluruh auditor independen yang bekerja pada Kantor Akuntan Publik (KAP) yang berada di Kota Padang dengan sampel sebanyak 68 orang auditor. Alasannya karena Kota Padang sudah banyak KAP besar maupun kecil, yang menuntut eksistensi auditor independen dalam melakukan pemeriksaan terhadap laporan keuangan dalam memberikan pendapat atas dasar pemeriksaan, sehingga keterlibatannya dalam penentuan kualitas audit.

Adapun teknik pengambilan sampel digunakan dalam penelitin ini adalah convenience sampling yaitu teknik 
pengambilan sampel dengan menyebar sejumlah kuesioner dengan menggunakan kuesioner yang kembali dapat diolah, dengan pendekatan purposive sampling yaitu teknik pengambilan sampel dengan kriteria tertentu.

\section{Variabel Penelitian dan Definisi Operasional \\ Variabel Dependen (Y) Kualitas Audit}

De Angelo (1981) dalam (Hanjani, 2014) mendefinisikan kualitas audit sebagai probabilitas dimana seorang auditor menemukan dan melaporkan tentang adanya suatu pelanggaran dalam sistem akuntansi kliennya. Pertanyaan mengenai variabel dapenden ini terdiri dari beberapa indikator. Setiap item diberi skor 1 sampai 4. Dengan menggunakan skala likert sebagai skala pengukuran skor 1 menunjukkan Sangat Tidak Setuju (STS). Skor 2 menunjukkan Tidak Setuju (TS). Skor 3 menunjukkan Setuju (S). Skor 4 menunjukkan Sangat Setuju (SS). Indikator yang digunakan untuk pengukur Kualitas Audit dalam penelitian ini adalah:

1. Kesesuaian pemeriksaan dengan standar audit,

2. Kualitas laporan hasil audit.

\section{Variabel Independen $\left(\mathbf{X}_{1}\right)$ Etika Auditor}

Etika dalam auditing adalah suatu proses yang sistematis untuk memperoleh serta mengevaluasi bukti secara objektif mengenai asersi-asersi kegiatan ekonomi, dengan tujuan menetapkan derajat kesesuaian antara asersi-asersi tersebut, serta penyampaian hasilnya kepada pihak-pihak yang berkepentingan.

Pertanyaan terdiri dari beberapa indikator. Setiap item diberi skor 1 sampai 4. Dengan menggunakan skala likert sebagai skala pengukuran skor 1 menunjukkan Sangat Tidak Setuju (STS). Skor 2 menunjukkan Tidak Setuju (TS). Skor 3 menunjukkan Setuju (S). Skor 4 menunjukkan Sangat Setuju (SS). Indikator yang digunakan untuk pengukur etika auditor dalam penelitian ini adalah:

1. Tanggung jawab profesi auditor

2. Integritas

3. Objektivitas.

\section{Variabel Independen $\left(\mathbf{X}_{2}\right)$ Pengalaman Auditor}

Pengalaman auditor dalam melakukan audit yang dilihat dari segi lainnya bekerja sebagai auditor dan banyaknya tugas pemeriksaan yang telah dilakukan.

Pertanyaan terdiri dari beberapa indikator. Setiap item diberi skor 1 sampai 4. Dengan menggunakan skala likert sebagai skala pengukuran skor 1 menunjukkan Sangat Tidak Setuju (STS). Skor 2 menunjukkan Tidak Setuju (TS). Skor 3 menunjukkan Setuju (S). Skor 4 menunjukkan Sangat Setuju (SS). Indikator yang digunakan untuk pengukur pengalaman auditor dalam penelitian ini adalah:

1. Lamanya bekerja sebagai auditor

2. Banyaknya tugas pemeriksaan.

\section{Variabel Independen $\left(\mathbf{X}_{3}\right)$ Motivasi Auditor}

Motivasi adalah proses yang menjelaskan intensitas, arah dan ketekunan usaha untuk mencapai suatu tujuan (Robbins, 2008). Motivasi yang membuat sumber daya manusia melakukan pekerjaanya sebaik mungkin.

Pertanyaan terdiri dari beberapa indikator. Setiap item diberi skor 1 sampai 4. Dengan menggunakan skala likert sebagai skala pengukuran skor 1 menunjukkan Sangat Tidak Setuju (STS). Skor 2 menunjukkan Tidak Setuju (TS). Skor 3 menunjukkan Setuju (S). Skor 4 menunjukkan Sangat Setuju (SS). Indikator yang digunakan untuk pengukur motivasi auditor dalam penelitian ini adalah:

1. Kesungguhan dalam menjalankan tugas sering dipengaruhi suasana hati

2. Penghargaan. 


\section{HASIL DAN PEMBAHASAN}

\section{Hasil Pengujian Validitas}

Hasil uji validitas yang dilakukan dengan bantuan SPSS versi 16.0 menunjukkan person correlation untuk setiap item butir pernyataan dengan variabel Kualitas Audit (Y), Etika Auditor (X1), Pengalaman Auditor (X2) dan Motivasi auditor (X3). Signifikan pada tingkat signifikansi 0,05 atau 0,01 .

\section{Tabel 1}

\section{Hasil Uji Validitas}

\begin{tabular}{|l|c|c|c|c|}
\hline \multicolumn{1}{|c|}{ Variabel } & $\mathbf{N}$ & $\begin{array}{c}\text { Person } \\
\text { Correlation }\end{array}$ & Signifikan & Keterangan \\
\hline Etika & 68 & $0,379-$ & $0,001-$ & Valid \\
Auditor & & 0,657 & 0,000 & \\
\hline Pengalaman & 68 & $0,382-$ & $0,001-$ & Valid \\
Auditor & & 0,663 & 0,000 & Valid \\
\hline Motivasi & 68 & $0,387-$ & $0,001-$ & \\
Auditor & & 0,513 & 0,000 & Valid \\
\hline Kualitas & 68 & $0,409-$ & $0,000-$ & 0,000 \\
Audit & & 0,603 & 0,000 & \\
\hline
\end{tabular}

Sumber : Data primer diolah dengan SPSS Ver.16.0

Berdasarkan hasil uji validitas pada tabel 4.11 diatas diketahui person correlation pada item nomor 1 yaitu etika auditor adalah sebesar 0,379-0,657, pada item nomor 2 yaitu pengalaman auditor adalaah sebesar 0,3820,663 , pada item nomor 3 yaitu motivasi auditor adalah sebesar 0,387-0,513, dan pada item nomor 4 yaitu kualitas audit adalaah sebesar 0,409-0,603. Hasil tersebut menunjukkan bahwa ke empat item adalah valid karena nilai $r$ hitung lebih besar dari 0,30 . Hasil uji validitas juga dapat dilihat dengan tingkat signifikannya yang menyatakan variabel independen dan variabel dependen adalah valid yaitu kecil dari 0,05 (taraf nyata tingkat signifikan).

\section{Hasil Uji Reliabilitas}

Hasil uji realibilitas pada penelitian ini menunjukkan bahwa nilai cronbach's Alpha ( $\alpha)$ untuk masing-masing variabel adalah > 0.60 dengan demikian dapat disimpulkan bahwa item-item instrument untuk masing-masing variabel adalah reliable.
Tabel 2

Hasil Uji Reliabilitas

\begin{tabular}{|l|c|c|c|}
\hline Variabel & $\begin{array}{c}\text { N of } \\
\text { items }\end{array}$ & $\begin{array}{c}\text { Cronbach's } \\
\text { Alpha }\end{array}$ & Keterangan \\
\hline $\begin{array}{l}\text { Etika } \\
\text { Auditor }\end{array}$ & 12 & 0.864 & Reliabel \\
\hline $\begin{array}{l}\text { Pengalaman } \\
\text { Auditor }\end{array}$ & 8 & 0.817 & Reliabel \\
\hline $\begin{array}{l}\text { Motivasi } \\
\text { Auditor }\end{array}$ & 8 & 0.725 & Reliabel \\
\hline $\begin{array}{l}\text { Kualitas } \\
\text { audit }\end{array}$ & 10 & 0.847 & Reliabel \\
\hline
\end{tabular}

Sumber : Data primer diolah dengan SPSS Ver.16.0

\section{Hasil Uji Normalitas}

Uji normalitas bertujuan untuk menguji apakah dalam model regresi, variable dependen dan independen keduanya mempunyai distribusi normal atau tidak (Ghozali, 2006). Model regresi yang baik adalah yang memiliki distribusi normal atau mendekati normal. Hasil pengujian normalitas dari keempat variabel penelitian dengan uji statistik menggunakan one-sample kolmogrof smirnov test.

Tabel 3

One-Sample Kolmogorov-Smirnov Test

\begin{tabular}{|c|c|c|}
\hline & $\begin{array}{c}\text { Unstandardized } \\
\text { Residual }\end{array}$ \\
\hline \multicolumn{2}{|l|}{$\mathrm{N}$} & 68 \\
\hline \multirow{2}{*}{$\begin{array}{l}\text { Normal } \\
\text { Parameters }\end{array}$} & Mean & .0000000 \\
\hline & Std. Deviation & 1.84117959 \\
\hline \multirow{3}{*}{$\begin{array}{l}\text { Most Extreme } \\
\text { Differences }\end{array}$} & Absolute & .110 \\
\hline & Positive & .110 \\
\hline & Negative & -.061 \\
\hline \multicolumn{2}{|c|}{ Kolmogorov-Smirnov Z } & .909 \\
\hline \multicolumn{2}{|c|}{ Asymp. Sig. (2-tailed) } & .380 \\
\hline
\end{tabular}

a. Test distribution is Normal.

Sumber : Data primer diolah dengan SPSS Ver.16.0

Hasil uji normalitas pada tabel diatas terlihat bahwa nilai Asymp. Sig (2-tailed) seluruh variabel yaitu etika, pengalaman, motivasi auditor dan kualitas audit lebih 
besar dari nilai alpha yaitu sebesar 0,05. Dengan demikian data yang digunakan dalam penelitian ini adalah normal.

\section{Hasil Uji Multikolinearitas}

Uji multikolonieritas bertujuan untuk menguji apakah model regresi ditemukan adanya korelasi antar variabel bebas (independent variabel). Model regresi yang baik seharusnya tidak terjadi korelasi di antara variabel independen. Apabila hasil analisis menunjukkan nilai VIF dibawah 10 dan tolerance value diatas 0,10 maka tidak terjadi multikolonieritas, sehingga model reliable sebagai dasar analisis(Ghozali, 2006).

\section{Tabel 4}

\section{Hasil Uji Multikolinearitas}

\begin{tabular}{|c|c|c|c|c|c|c|c|}
\hline \multicolumn{8}{|c|}{ Coefficients } \\
\hline \multirow[b]{2}{*}{ Model } & \multicolumn{2}{|c|}{$\begin{array}{l}\text { Unstandardized } \\
\text { Coefficients }\end{array}$} & \multirow{2}{*}{\begin{tabular}{|c}
$\begin{array}{c}\text { Standardized } \\
\text { Coefficients }\end{array}$ \\
Beta \\
\end{tabular}} & \multirow[b]{2}{*}{$\mathrm{t}$} & \multirow[b]{2}{*}{ Sig. } & \multicolumn{2}{|c|}{$\begin{array}{c}\text { Collinearity } \\
\text { Statistics }\end{array}$} \\
\hline & B & Std. Error & & & & Tolerance & VIF \\
\hline 1 (Constant) & 13.080 & 3.289 & & 3.977 & .000 & & \\
\hline $\mathrm{X} 1=$ Etika Auditor & .398 & .095 & .511 & 4.183 & .000 & .571 & 1.752 \\
\hline $\begin{array}{l}\text { X2=Pengalaman } \\
\text { Auditor }\end{array}$ & -.346 & .150 & -.286 & 2.311 & .024 & .557 & 1.795 \\
\hline X3=Motivasi Auditor & .587 & .137 & .457 & 4.271 & .000 & .745 & 1.343 \\
\hline
\end{tabular}

Sumber : Data primer diolah dengan SPSS Ver.16.0

Dapat dilihat besaran korelasi antar variabel bebas yang mempunyai korelasi yang cukup tinggi, maka dapat dikatakan tidak terjadi multikolinearitas. Hasil perhitungan tolerance juga menunjukkan bahwa tidak adanya variabel bebas yang memiliki nilai tolerance value diatas 0,10 Hasil perhitungan nilai VIF juga menunjukkan hal yang sama, tidak ada variabel bebas yang memiliki nilai VIF dibawah 10. Dari hasil uji multikolineariitas dapat diambil kesimpulan bahwa variabelvariabel yang diuji dalam penelitian ini menunjukkan tidak terdapat gejala multikolinearitas diantara variabel independen.

\section{Hasil Uji Heteroskedastisitas}

Dalam penelitian ini hasil uji heteroskedastisitas dapat diketahui dengan melihat pola grafik scatterplots menggunakan aplikasi SPSS. Apabila sebaran titik tidak membentuk suatu pola/alur tertentu karena titik menyebar tidak beraturan, maka dapat disimpulkan tidak terjadi heteroskedastisitas atau dengan kata lain terjadi homoskedastisitas.

\section{Gambar 1 \\ Hasil Uji Heteroskedastisitas}

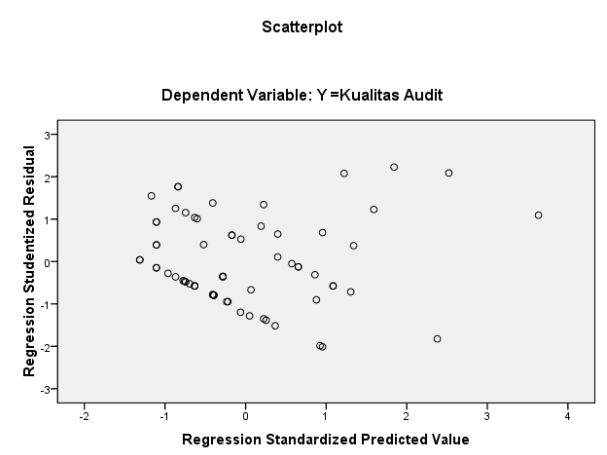

Sumber : Data primer diolah dengan SPSS Ver.16.0

Dapat dilihat dari grafik scatterplot diatas, jelas bahwa tidak ada pola tertentu karena titik menyebar tidak beraturan. Maka dapat disimpulkan bahwa tidak terjadi gejala heteroskedastisitas.

\section{Hasil Uji Autokorelasi}

Uji autokorelasi bertujuan menguji apakah dalam model regresi linear ada korelasi antara kesalahan pengganggu pada periode $\mathrm{t}$ dengan kesalahan pengganggu pada periode t-1 (sebelumnya)(Ghozali, 2006). Autokorelasi timbul karena residual (kesalahan pengganggu) tidak bebas dari satu observasi lainnya. Hal ini sering ditemukan pada data runtun waktu (time series). Cara yang dapat digunakan untuk mendeteksi ada atau tidaknya autokorelasi antara lain dengan melihat tabel dibawah ini :

\section{Tabel 5}

\section{Hasil Uji Autokorelasi}

Model Summary ${ }^{b}$ 


\begin{tabular}{|l|l|r|r|r|r|}
\hline Model & $\mathrm{R}$ & $\begin{array}{c}\mathrm{R} \\
\text { Square }\end{array}$ & $\begin{array}{c}\text { Adjusted } \\
\text { R Square }\end{array}$ & $\begin{array}{c}\text { Std. Error } \\
\text { of the } \\
\text { Estimate }\end{array}$ & $\begin{array}{c}\text { Durbin- } \\
\text { Watson }\end{array}$ \\
\hline 1 & $.674^{\mathrm{a}}$ & .454 & .428 & 1.884 & 1.550 \\
\hline
\end{tabular}

a. Predictors: (Constant), X3=Motivasi Auditor, $\mathrm{X} 1=$ Etika Auditor, $\mathrm{X} 2=$ Pengalaman Auditor

b. Dependent Variable: Y

=Kualitas Audit

Sumber : Data primer diolah dengan SPSS Ver.16.0

Pada hasil uji regresi melalui SPSS ver.16.0 yang terlihat pada tabel 4.16 dibawah ini menghasilkan nilai Durbin Watson sebesar 1,550 disimpulkan bahwa tidak terjadi gejala autokorelasi. Karena berdasarkan kriteria nilai Uji Durbin Watson (Uji DW) nilai DW 1,65 < DW < 2,35 tidak terjadi masalah autokorelasi.

\section{Hasil Analisis Regresi Berganda dan Hasil Uji Hipotesis}

Setelah melakukan pengujian asumsi klasik dan hasilnya secara keseluruhan menunjukkan model regresi yang memenuhi asumsi klasik, maka tahap selanjutnya adalah melakukan pengujian hipotesis.

\section{Tabel 6}

Analisis Regresi dan Uji Hipotesis

\begin{tabular}{|l|r|r|c|c|c|}
\hline \multicolumn{1}{|c|}{$\begin{array}{c}\text { Variabel } \\
\text { Penelitian }\end{array}$} & $\begin{array}{c}\text { Koefisien } \\
\text { Regresi }\end{array}$ & $\begin{array}{c}\text { Std. } \\
\text { Error }\end{array}$ & Sig & Alpha & Kesimpulan \\
\hline (Constanta) & 13.080 & 3.289 & .000 & - & - \\
\hline Etika Auditor & .398 & .095 & .000 & 0,05 & Signifikan \\
\hline $\begin{array}{l}\text { Pengalaman } \\
\text { Auditor }\end{array}$ & -.346 & .150 & .024 & 0,05 & Signifikan \\
\hline Motivasi Auditor & .587 & .137 & .000 & 0,05 & Signifikan \\
\hline R & & & & & \\
\hline F-sig & 0,428 &
\end{tabular}

Sumber : Data primer diolah dengan SPSS Ver.16.0

Pada tabel coefficients yang diinterpretasikan adalah nilai dalam kolom B, baris pertama menunjukkan konstanta variabel (a) dan baris selanjutnya menunjukkan konstanta variabel independen. Model regresi yang terbentuk berdasarkan penelitian ini adalah :

$$
Y=13.080+0.398 X_{1}-0.346 X_{2}+0.587 X_{3}
$$

Persamaan regresi linear berganda diatas dapat diketahui bahwa konstanta bernilai positif sebesar 13.080. Hal ini menunjukkan bahwa jika semua variabel bebas dianggap konstan, maka besarnya nilai kualitas audit bernilai sebesar 13.080. Dan koefisien regresi variabel etika $\left(\mathrm{X}_{1}\right)$ bernilai positif sebesar 0.398 , menunjukkan hubungan fungsional antara hubungan etika auditor dengan kualitas audit berbanding lurus atau searah (bernilai positif). Koefisien regresi variabel etika auditor $\left(\mathrm{X}_{1}\right)$ mengandung arti untuk setiap etika auditor sebesar satu satuan akan meningkatnya kualitas audit (Y) sebesar 0.398 . Koefisien regresi variabel pengalaman auditor $\left(\mathrm{X}_{2}\right)$ bernilai negatif sebesar $(-0.346)$ menunjukkan hubungan fungsional antara hubungan pengalaman auditor dengan kualitas audit mempunyai pengaruh berlawanan (bernilai negatif). Dan koefisien regresi variabel motivasi $\left(\mathrm{X}_{3}\right)$ bernilai positif sebesar 0.587. Hal ini menunjukkan hubungan fungsional antara hubungan motivasi auditor dengan kualitas audit berbanding lurus atau searah (bernilai positif). Koefisien regresi variabel motivasi auditor $\left(\mathrm{X}_{3}\right)$ mengandung arti untuk setiap etika auditor sebesar satu satuan akan meningkatnya kualitas audit (Y) sebesar 0.587 .

\section{Hasil Uji Hipotesis}

Kekuatan pengaruh variabel bebas terhadap variasi variabel terikat dapat diketahui dari besarnya nilai koefisien determinan $\left(\mathrm{R}^{2}\right)$. Dilihat dari tabel diatas, angka Adjusted $R$ Square adalah 0,428. $R^{2}$ disebut juga koefisien determinasi yang dalam hal ini mengandung arti bahwa 42,8\% kualitas audit dapat dijelaskan oleh variabel etika, pengalaman dan motivasi auditor. Dapat disimpulkan bahwa etika auditor, pengalaman auditor dan motivasi auditor memberikan pengaruh sebesar $42.8 \%$ terhadap kualitas audit pada Kantor Akuntan Publik di Kota Padang. Sedangkan sisanya 
$57,2 \%$ dipengaruhi oleh variabel lain yang tidak termasuk dalam model penelitian.

\section{Hasil Uji statistik t (Secara Parsial)}

Hasil uji secara parsial bertujuan untuk menguji pengaruh masing-masing variabel independen (etika, pengalaman dan motivasi auditor) terhadap variabel dependen (kualitas audit). Pengaruh dari masingmasing variabel etika auditor, pengalaman auditor dan motivasi auditor terhadap kualitas audit dapat dilihat dari arah tanda dan tingkat signifikan (probabilitas). Tingkat signifikansi variabel etika $(0,000)$ kurang dari taraf signifikansi (0,05), maka hipotesis 1 diterima. Hal ini membuktikan bahwa etika auditor berpengaruh positif terhadap kualitas audit. Dengan nilai t-statistik 4,183. Ini berarti semakin tinggi atau semakin baik etika auditor maka akan semakin baik kualitas audit operasionalnya.

Uji statistik menunjukkan bahwa tingkat signifikan variabel pengalaman auditor $(0,024)$ kurang dari taraf signifikansi $(0,05)$ maka secara hipotesis 2 diterima. Hal ini membuktikan bahwa pengalaman auditor berpengaruh positif terhadap kualitas audit. Dengan nilai t-statistik (-2.311). Ini berarti semakin tinggi pengalaman seorang auditor maka semakin baik kualitas audit yang diperolehnya.

Tingkat signifikansi variabel motivasi auditor $(0,000)$ kurang dari taraf signifikansi $(0,05)$ maka secara hipotesis 3 diterima. Hal ini membuktikan bahwa motivasi auditor berpengaruh positif terhadap kualitas audit. Dengan nilai t-statistik (4,271). Ini berarti semakin kuat motivasi atau dorongan seorang auditor maka semakin baik pula hasil kerja kualitas audit yang diperoleh.

\section{Hasil Uji Statisk F (Secara Simultan)}

Hasil uji F digunakan untuk mengetahui apakah variabel independen secara bersama-sama atau simultan memp=engaruhi variabel dependen. Berdasarkan tabel diatas bahwa hasil uji menyatakan $\mathrm{F}$ sebesar 17.722 dengan nilai signifikan value sebesar 0,000 yang lebih kecil dari $\alpha=0,05$. Jadi dapat disimpulkan bahwa model regresi yang digunakan dianggap layak uji.

\section{Pembahasan}

Pengaruh Etika Auditor terhadap Kualitas Audit

Berdasarkan uji t (parsial) pada model regresi, diperoleh nilai signifikansi variabel etika auditor sebesar $0,000<0,05$ (taraf nyata signifikansi penelitian). Dari hasil tersebut dapat disimpulkan bahwa $\mathrm{H}_{1}$ diterima, artinya secara parsial variabel etika auditor berpengaruh positif terhadap variabel kualitas audit.

Hasil penelitian ini didukung oleh penelitian sebelumnya yaitu penelitian yang dilakukan oleh Putra (2012), Hanjani (2014), penelitian oleh Kartika (2015), dan penelitian oleh Mufidah (2015). Yang menunjukkan bahwa etika auditor berpengaruh terhadap kualitas audit.

\section{Pengaruh Pengalaman Auditor terhadap Kualitas Audit}

Berdasarkan uji t (parsial) pada model regresi, diperoleh nilai signifikansi variabel pengalaman auditor sebesar 0,024 $<0,05$ (taraf nyata signifikansi penelitian). Dari hasil tersebut dapat disimpulkan bahwa $\mathrm{H}_{2}$ diterima, artinya secara parsial variabel pengalaman auditor berpengaruh positif terhadap variabel kualitas audit.

Hasil penelitian ini didukung oleh penelitian sebelumnya yaitu penelitian yang dilakukan oleh Putra (2012), penelitian oleh Hanjani (2014) dan penelitian oleh Kartika (2015). Menunjukkan hasil bahwa pengalaman auditor berpengaruh terhadap kualitas audit. Dengan pengalaman dalam bidang audit, maka auditor akan dapat menyelesaikan auditnya dengan baik sehingga mampu menghasilkan kualitas audit yang memadai. 


\section{Pengaruh Motivasi Auditor terhadap Kualitas Audit}

Berdasarkan uji t (parsial) pada model regresi, diperoleh nilai signifikansi variabel pengalaman auditor sebesar $0,000<0,05$ (taraf nyata signifikansi penelitian). Dari hasil tersebut dapat disimpulkan bahwa $\mathrm{H}_{3}$ diterima, artinya secara parsial variabel motivasi auditor berpengaruh positif terhadap variabel kualitas audit. Hasil penelitian ini didukung oleh penelitian sebelumnya yaitu penelitian yang dilakukan oleh Ardini (2010) dan Hanjani (2014). Yang menunjukkan hasil bahwa motivasi berpengaruh terhadap kualitas audit.

Dengan demikian, apabila seseorang atau auditor mempunyai kompetensi, independensi dan pengalaman maka akan mengarahkan atau menimbulkan motivasi secara profesional dengan adanya motivasi yang tinggi maka akan menambah kualitas audit yang memadai.

\section{Pengaruh Etika Auditor, Pengalaman Auditor dan Motivasi Auditor terhadap Kualitas Audit}

Berdasarkan hasil pengujian hipotesis uji $\mathrm{F}$ pada model regresi diatas, didapat nilai signifikansi $0,000<0,05$ (taraf nyata signifikansi penelitian). Dari hasil tersebut, maka dapat disimpulkan bahwa secara bersama-sama atau secara simultan variabel independen yaitu etika auditor, pengalaman auditor dan motivasi auditor berpengaruh positif secara simultan terhadap variabel dependen yaitu kualitas audit.

\section{SIMPULAN}

Penelitian ini bertujuan untuk memberi bukti empiris pengaruh etika auditor, pengalaman auditor, dan motivasi auditor terhadap kualitas audit. Berdasarkan hasil penelitian, maka kesimpulan dari penelitian ini adalah sebagai berikut :

1. Etika auditor berpengaruh positif terhadap kualitas audit. Etika berpengaruh positif dan signifikan sebesar $0,000<0,05$ terhadap kualitas audit dalam auditor yang bekerja pada KAP di wilayah Kota Padang.

2. Pengalaman auditor berpengaruh positif terhadap kualitas audit. Pengalaman berpengaruh positif dan signifikan sebesar $0,024<0,05$ terhadap kualitas audit pada KAP di wilayah Kota Padang.

3. Motivasi auditor berpengaruh positif terhadap kualitas audit. Motivasi berpengaruh positif dan signifikan sebesar $0,000<0,05$ terhadap kualitas audit pada Kantor Akuntan Publik diwilayah Kota Padang

4. Secara simultan variabel etika, pengalaman, dan motivasi berpengaruh positif dan signifikan sebesar $0,000<$ 0,05 terhadap variabel kualitas audit yang dihasilkan oleh auditor pada KAP di wilayah Kota Padang.

\section{REFERENSI}

Amrizal. (2014). Analisis Kritis Pelanggaran Kode Etik Profesi Akuntan Publik di Indonesia. Jurnal Liquidity, 3(1), 36-43.

Ardini, L. (2010). Pengaruh Kompetensi, Independensi, Akuntabilitas, dan Motivasi Terhadap Kualitas Audit. Majalah Ekonomi, 3(XX).

Ghozali, I. (2006). Aplikasi Analisis Multivariat Dengan Program SPSS (Cetakan Ke). Semarang: Badan Penerbit Universitas Diponegoro.

Hanjani, A. (2014). Pengaruh Etika Auditor, Pengalaman Auditor, Fee Audit dan Motivasi Auditor Terhadap Kualitas Audit. Universitas Diponegoro.

Kartika, D. (2015). Pengaruh Pengalaman Auditor dan Etika Auditor Terhadap 
Kualitas Audit. Universitas Pasundan.

Mufidah. (2015). Pengaruh Kompetensi, Etika, Fee Audit Terhadap Kualitas Audit. Universitas Muhammadiyah Surakarta.

Putra. (2012). Pengaruh Kompetensi, Tekanan Waktu, Pengalaman Kerja, Etika dan Indpendensi Auditor Terhadap Kualitas Audit. Universitas Negeri Yogyakarta.

Robbins, S. dan J. (2008). Prilaku Organisasi. Jakarta: Salemba Empat.

Simanjuntak, P. (2008). Pengaruh Time Budget Pressure dan Risiko Kesalahan Terhadap Penurunan Kualitas Audit. Universitas Diponegoro, Tesis. 